\title{
VAPOURABLE SUBLIME: AQUATECTURE EXPERIMENT AND PROJECT REVIEW
}

\author{
DOI: 10.18485/arh_pt.2020.7.ch52
}

\author{
_ Miloš Stojković \\ M.Arch., Teaching Assistant, PhD student, University of Belgrade \\ Faculty of Architecture, Belgrade, Serbia, milos.stojkovic@arh.bg.ac.rs
}

\begin{abstract}
There is hardly anything that entices pure awe and a feeling of the sublime as ruins of a historic manor. Notions evoked by such ruins confine strong sensations of longing for a non-discernible object of loss. Taking that into consideration, this paper takes everything a step further - it dematerialises the formal language of manorial architecture and challenges the intuitive melancholic sensations of the visitor. It eliminates the habitually known architectural elements of a manor and calls for a rewriting of space and atmosphere. In the described research, water is the key element, as all of its states are familiar to humans and thus serve as an effective stimulation of the senses. The most sublime state of water is vapour. It is manifested here as a visible exhalation of the ruin, a mist that disintegrates architecture, dematerialises space and annihilates gravity. Vapour makes the architecture insubstantial and human emotions transitory. It provides strange, senseless and fantastic notions which rewrite architectural design, offering new methods for applying water in landscape architecture, heritage and tourism. The aim of this paper is to present the aquatic phenomenon in architecture: the structure of space by water as a primordial element. The case study for this research was a competition project for Château de la Mothe Chandeniers_in France. Designed according to doctoral research on relations between water and architecture, and offering a responsible design approach and a unique methodology, the project deliberates upon those two commonly known notions, while adding the third - Aquatectural common ruin as innovative method of revitalization of built heritage.
\end{abstract}

KEYWORDS _ aquatecture, water, vapour, sublime, experiment, heritage

\section{INTRODUCTION: THE COMMON RUIN}

At the beginning of 2019, the international team of young professionals (design team members: Boris Dundović, Lidija Lukić, Petar Tošić, Luka Stijović, Stefan Lakić and Miloš Stojković), had the opportunity to work on a unique competition project, organized by YAC - Young Architects Competitions, with the aim of promoting contemporary solutions that embody a temporal and personal approach to architectural space. The architectural competition was entitled Common ruins (Young Architects Competitions [YAC], 2018), and we named our Project for this competition Vapourable Sublime.

There is a special fascination in ruins, when we can feel a sublime hint in dissolved architectures, as we flow through the pulverization of time. During those moments, when silence takes over architecture and gives it to the water, Aquatecture is born (YAC, 2018; Wylson, 1986). In the long sunset that follows abandonment and preludes destruction, nature completes the design of humankind by taking space back according to its own pace. In that moment, something magical happens. In that moment, architecture gives way to ruins. And we can say that the Renaissance castle of Mothe 
Chandeniers is one of a kind, a unique, perfect ruin. This structure is an enchanted mirage fluctu $\neg$ ating on a calm lake, which creates a perfect Spatial image of Aquatecture (Stojković, 2019), one that had to be lost in order to be found in the romantic French countryside (YAC, 2018).

\section{SITE AND INTERVENTION}

"There is hardly anything that entices pure awe and a feeling of the sublime as ruins of a historic manor. Notions evoked by such ruins confine strong sensations of longing for a non-discernible object of loss. Taking that into consideration, this paper takes everything a step further - it dematerialises the formal language of manorial architecture and challenges the intuitive melancholic sensations of the visitor. It eliminates the habitually known architectural elements of a manor and calls for a rewriting of space and atmosphere. By challenging the visitor's senses, it persuades an individual to reflect on one material substance and physical presence." (Dundović, 2019, 1).

Before going further, and before a deep explanation of the project and methodology, we must mention that Mothe Chandeniers is not too far from the magnificent castles (châteaux and manoirs) that made the Loire valleys famous. The Castle is situated in a context which is perfect for a dreamy scenario for the act of human creation of the Myth and the Concept of Sublimity (Popović \& Milenković, 2015), or more appropriately for an aquatecture project as unique as the house of water (Stojković, 2019). The site as an extended countryside separates the castle from the main towns; consequently, the visitors of the site have the impression of traveling through time. Golden fields and thick woods that surround the site lead to quiet villages with bluish sloping roofs and solid chimneys. Such elements evoke settings more fitting for Alexander Dumas rather than the scenary of a contemporary France. Scattered towers covered in ivy overlook lavender and wheat fields. Roses, lilies and petunias embellish vegetable gardens and porticos. Every element of this unique architectural work contributes to creating a sense of conciliation evoked by the smell of hay and the quiet dance of the fronds of willow trees. The ancient Aquitaine region is truly an oasis of peace. Only flying doves and hunting shots interrupt its peaceful silence (YAC, 2018,6). Such a description can be recognized as a "fragile" perception of space, giving life to inspiration on the road to profound learning, all in the name of understanding and making of a contemporary architectural space (Pallasmaa, 2017, 57). In our design, we consider this meaningful context of the castle, and by doing so, we propose an efficient tourism and accommodation scenario with a unique intervention achieved by blurring the boundaries. The structure of the castle was affected by decades of abandonment and its static performances are consolidated in a series of up-to-date structural architectural interventions, both indoor and outdoor. They enhanced the visit, the discovery and the unique potential of the castle as a romantic site made of the architecture of sublime dreams (Popović \& Milenković, 2015).

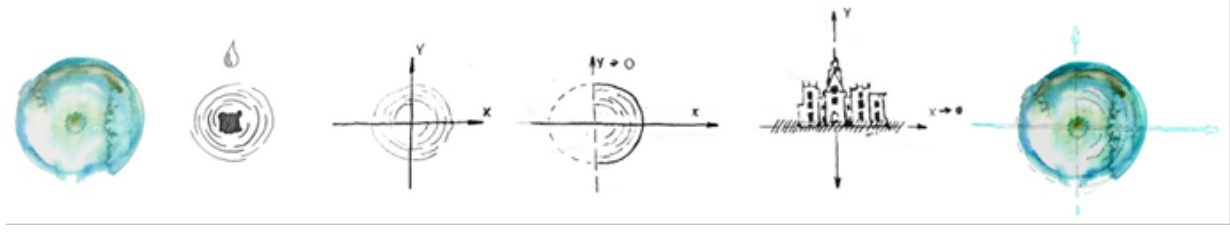

_ Figure 1: Design concept \& conceptual idea, Vapourable Sublime project diagrams and sketches, authors: Boris Dundnović, Lidija Lukić, Petar Tošić, Luka Stijović, Stefan Lakić and Miloš Stojković, 2019.

The implemented intervention can be split into two zones. The first zone is comprised of the castle interior, followed by the moat, and including the nearby chapel. Our intervention is aimed at enhancing the visitor's perception of the castle, with new routes and platforms, volumes and floating structures, enriched by an open air (aquatic) theatre and an artificial island scene with hydraulics, sound 
and lighting systems. The second zone consists of the gardens around the castle and the lake, accentuated by a newly formed semi-circular structure above the ground, with a multifunctional rooftop, arising conceptually from the arc of a water drop (Fig. 1), marking a central axis and its route that improves the usability of the castle (Fig. 4). These kinds of interventions are to guarantee fascinating and improved views of the castle, respecting both nature and historical architecture in situ.

\section{AQAUTECTURE PROJECT: VAPOURABLE SUBLIME}

At the beginning of the study, the intervention is described as a setting for intuitive melancholic sensations and a dreamy, sublime vessel (a kind of sublime dream) for rewriting space and atmosphere. Now we can say that in the described mechanism, water is the key element, as all of its states are familiar to the visitor and thus serve as an effective stimulation of the senses. That notion appears as a leitmotif throughout all parts of the depicted project. The most sublime state of water is vapour. It is manifested here as a visible exhalation of the ruin, a mist that disintegrates architecture, dematerialises space and annihilates gravity. Vapour makes architecture insubstantial and the visitor's emotions transitory. It provides strange, senseless and fantastic notions which rewrite the overall story of the chateau with each visitor. On a wider scale, the ruin itself functions as a water droplet. It emanates vectors, emits surfaces and structures which physically manifest as ripples crystallized in time (Dundović, 2019). Conclusively, the common ruin of the manor transcends the known physicality and emerges as a notion of sublimity - that is, the Vapourable Sublime (Fig. 2).

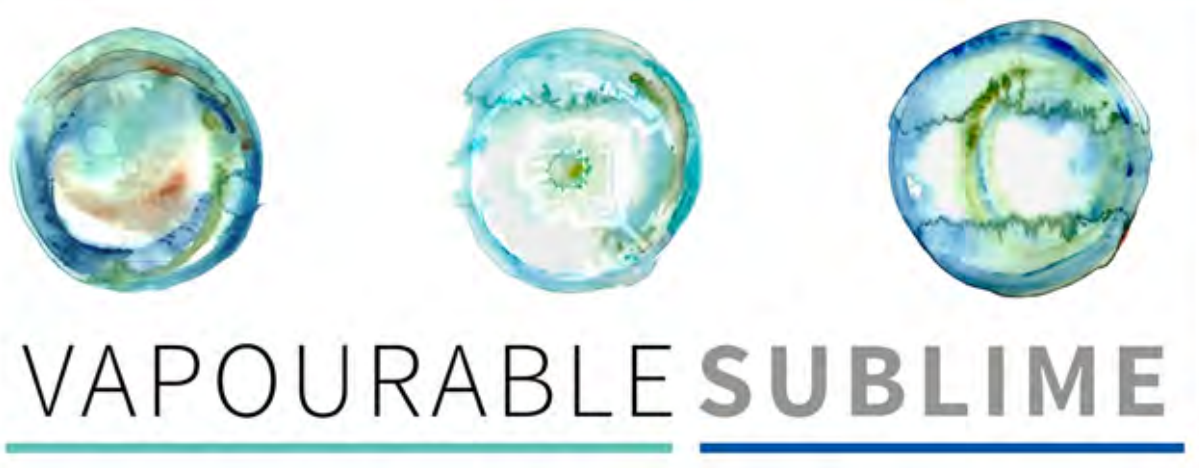

_ Figure 2: Vapourable Sublime - Conceptual aquatecture diagram (aquarelle triptych), author: Miloš Stojković, 2019.

As the focal point of the site, the manor is a node that dictates the intensity of spatial vectors oriented towards it. In this project, the vectors affecting the manor and turning it into a ruin are emanating beyond physical boundaries, spreading to the surrounding area, manifesting in the water that envelops it, in surfaces and objects that make a new architectural disposition. The manor is envisioned as an artistic space where a sequence of rooms (circular enfilade) and salons serves as a kind of exhibition hall. The rooms present contemporary art and architecture installations in dialogue with the historic ruin. Starting with the first room (sala baronale - Fig. 6), the visitor is introduced to elements of manorial architecture, but the newly embedded elements also suggest that it is a place of reconsideration. Room by room, the contemporary elements overtake the ruin architecture, disintegrating it into atmospheres. The visitor's senses are also gradually challenged, until common concepts like sight, touch, gravity and other sensory information is completely out of reach. It is lost in pools of black, in metal, in fog and mirrors, so that when the visitor returns to the central courtyard (cortille) where they started, they are immediately splashed with a strong return of physicality and emotions (Dundović, 2019, 1), indulging in the Sublime Dream (Fig 3). 


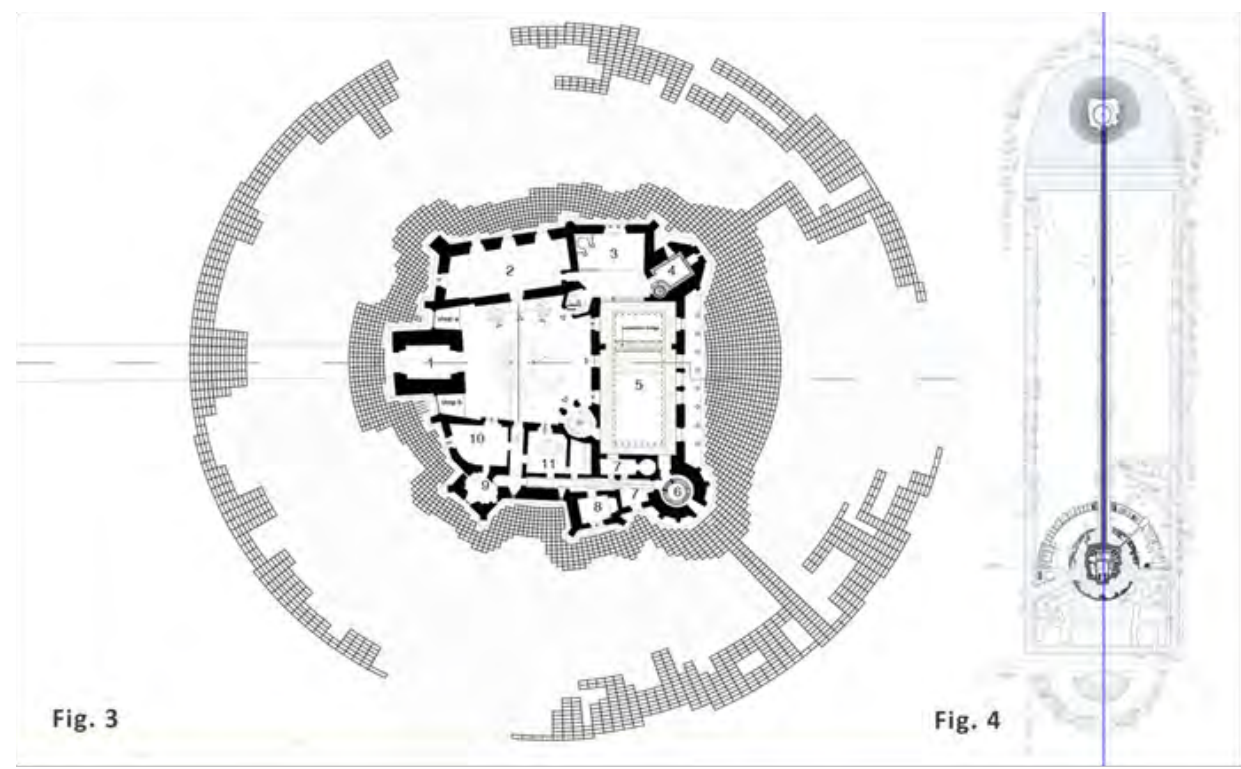

_ Figure 3 \& 4: Vapourable Sublime project - Floor plan of the chateau \& use of the space: 1 - Entrance (shop a/b), 2 - Baronial hall (soil/sand/gravel), 3 - Black/Blue floor room, 4 - Water room, 5 - Steam hall, 6 - Installation, 7 - Ice room, 8/9 - Gallery spaces, 10 - Library, 11 - Office, authors: Boris Dundović, Lidija Lukić, Petar Tošić, Luka Stijović, Stefan Lakić and Miloš Stojković, 2019; Vapourable Sublime project Site plan of the chateau and manor central axis, authors: Boris Dundović, Lidija Lukić, Petar Tošić, Luka Stijović, Stefan Lakić and Miloš Stojković, 2019.
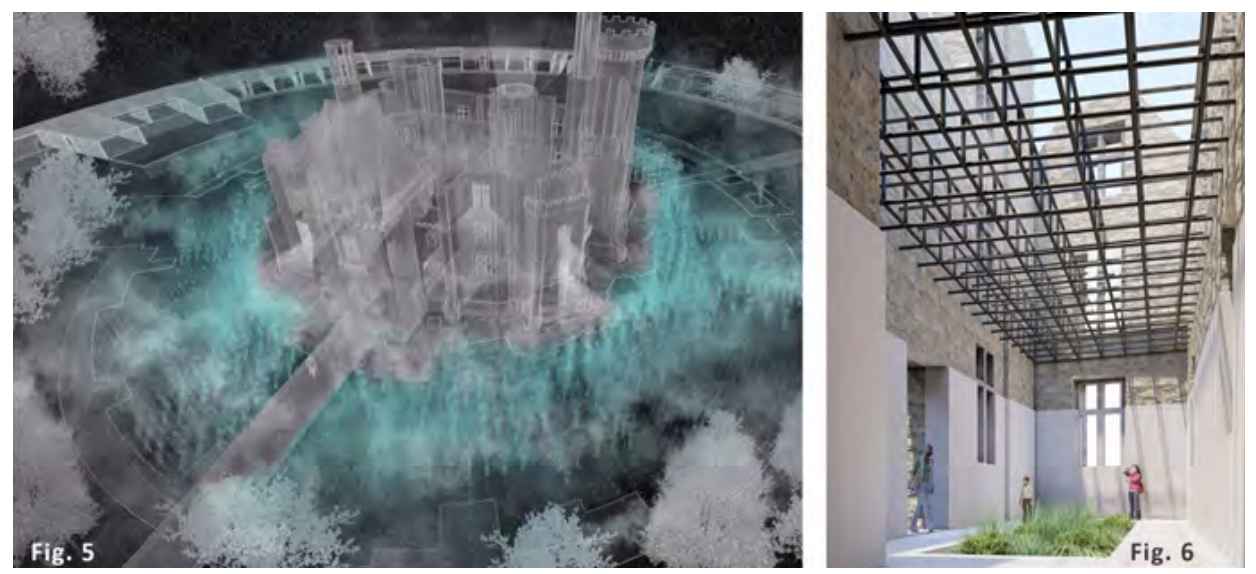

_. Figure 5 \& 6: Vapourable Sublime project - Exterior and interior ambients (Fig. 6 Exibition hall - sala baronale), authors: Boris Dundović, Lidija Lukić, Petar Tošić, Luka Stijović, Stefan Lakić and Miloš Stojković, 2019.

The most significant of the vectors is the central axis of the manorial site, which dictates the symmetry of the estate and which centres the courtyard of the ruin. While it emanates from the manor house ruin, its conclusion is marked by a lake with an island (Fig. 4). The manor is a central point for new architecture that surrounds it. As scenography, it visually "exhales mnemonic vapours" to 
the surrounding space, materialising the idea of the manor house that once was. On the other hand, the new architecture also uses certain elements reminiscent of the manor, such as stone walls and white walls, but it reverses relations between these elements to accommodate new functions (Fig. 5\&6). The deconstructed elements are oriented as vectors towards the manor (Dundović, 2019, 1).

"The outline of the manor doubles not only in the mirror canal, but also in the small lake opposing the original structure. Placed one towards the other, the duality of manors once again contrasts the notions of real and virtual, of material and transcendent, and of manorial and vapourable." (Dundović, 2019, 1)

\section{Competition briefing and the program of Common Ruin as Vapourable Sublime}

The issue of the relationship between artificial and natural is a funda-mental feature of a place where water is the key element that surrounds the ruin. In the castle, ar-chitecture, nature and history tell their most remarkable story. The challenge of Mothe Chandeniers deals with the mysterious relationship between the different elements that compose the unique beauty of this place (YAC, $2018,8)$. With water as the key element in that equation, the Castle can became a true Aquatecture project and a unique House of water (Stojković, 2019). It also deals with uses and new accommodation models. Consequently, the intentions are focused on the individual and experiential discovery methodology of the ruins as part of visit models that can be observed as open and as common as possible. Therefore, what is offered is an exclusive, interior and outdoor emotional experrience for future visitors (consistent with the nature of the castle and water around it by creating floating platforms with mist, (Fig. 7).
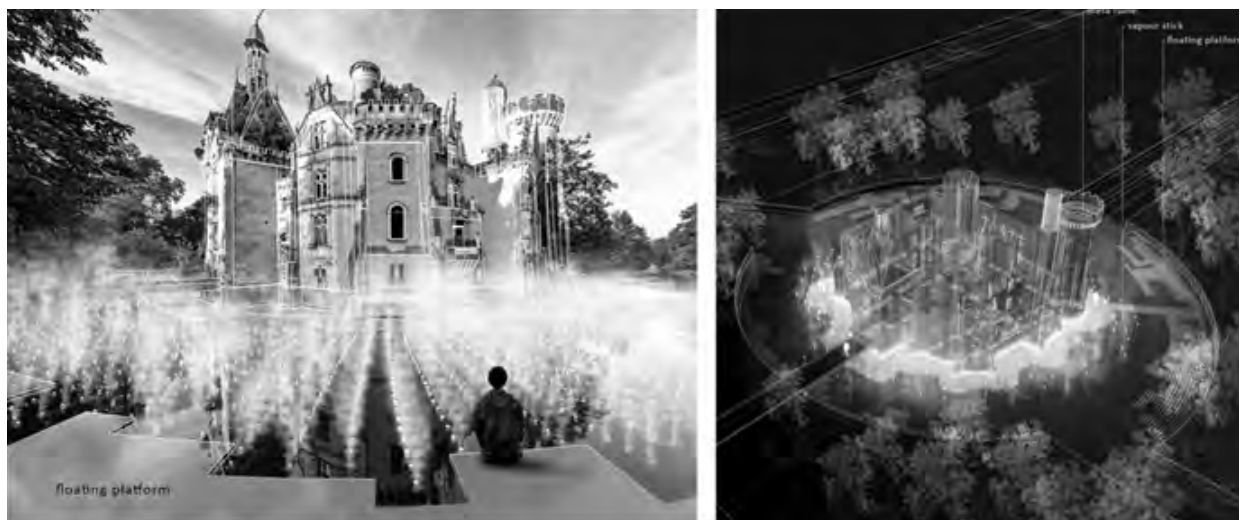

_ Figure 7: Vapourable Sublime project - Floating platforms with mist, ambient and axonometry (diptych), authors: Boris Dundović, Lidija Lukić, Petar Tošić, Luka Stijović, Stefan Lakić and Miloš Stojković, 2019.

Here-by follows a paraphrase of different functional and program possibilities we offered in our project for a Castle revitalization (following the instruction from the Competition briefing): 1. Visitors' center: we create an architectural route in and around the castle (inspired by a water drop). It will have to ensure the knowledge of the fortress' history, in-cluding a series of spectacular views of the ruin. This is one of the numerous elements aiming at witnessing and enhancing the inherited story of the castle; 2 . Shop: this place will include the merchandise of the castle and a specialized bookshop, conceived as a space next to the entrance before one enters the sequence of rooms the circular enfilade (Fig. 3); 3 . Restaurant/biofarm: in this area visitors will have the opportunity to enjoy a refreshing break, tasting French food and wine specialties, as the restaurant and biofarm are to be located in the new archi-structure, on the bank of the lake next to the water, near the chapel (which is left intact); 4 . Theater and events area: Mothe Chandeniers provides extraordinary natural and architectural scenography. It is the perfect set design for any show or artistic/musical performance. Today, as in the 16th century, the Castle will host actors, musicians and performers. There- 
fore, three stages are placed along the central axis of the manorial site. The first and the biggest - at the entrance, the second one in front of the Castle on the water with floating platforms (where facade of Castle makes a unique scenography), and the third as an island scene at the outskirts of the manorial site; all three stages can be called the Aquatic theatre (Stojković, 2019); 5. Castle villas: Mothe Chandeniers is to en-sure sufficient hospitality solutions for all those visitors who want to escape their everyday routine in order to relax in the castle. Anytime during the year, Mothe Chandeniers can guarantee a remarkable and prodigious splendor, also thanks to the ever-changing sky and colors of nature. Thus, we propose a right wing of the new archi-structure for this residential purpose. We also added Minimal modules around the ruin, floating elements on water stretches, with facilities (springs and vapour sticks) which can create a mist (Dsrny. 2002) framing the suggestive views of the castle and allowing a walk on water (Christo and Jeanne Claude. 2016), forming the unique Image of the Space (Stojković, 2019); 6. Wellness services: observing the castle covered in snow immersed in the vapors of a heating swimming pool is just one of the possible scenarios of wellness services. They are to be private and situated in front of the villas with a view of the facade of the Castle. The integration of such water elements will guarantee a unique and unforgetta-ble experience of the castle; 7. Nature and ruins observatory: It is an equipped trail aimed to better discover the castle and its surrounding nature. We proposed a rooftop trail which supplements the central axis trail in Castle and the water as Gangways connecting the ruins, meditation and relaxation spaces or panoramic viewpoints (YAC, 2019, 8-9). This kind of treatment shall guide visi-tors in a unique experience of a vapourable sublime. These indoor and outdoor trails (decking paths) will enable visitors to stand on the elements that slightly touch the water, observe sensual roots twining the castle and find hidden friezes, art, sculptures and installations, such as ice, aquatic and vegetative rooms and halls, oculus corridors, or kaleidoscopic sky installations in towers of a glass-roofed castle.

\section{INITIAL RESEARCH AND METHODOLOGY: AQUATECTURE EXPERIMENT}

The initial research was conducted as part of my post-graduate studies, during the second year of the Doctoral Academic Studies in Architecture and Urbanism at the University of Belgrade, from March 2017 to February 2018. The experimental research for this, now freely called aquatectural project and study, was created in the elective course Architecture and Visual Language, under the mentorship of Professor Branko Pavić. The name of this initial research was Water: inspiration in architectural space design - methodological experiments. The research looked at four case studies (in Serbia and Croatia, guided by the criterion of being related to a water element). Those locations, from which the water sample was taken in order to emulate scientific (artistic) poetical information, as relevant to architectural practice, can be colors (through the formation of tone maps for a specific place or object) and shapes (made for new or existing structures) during the design research process or the process of revitalization (Stojković, 2018).

It is also important to note at the end, that the design research carried out in this paper is presented in the architecture design and a study (Conceptual Design). The framework in this process is based on the integration of theoretical and pragmatic design aspects using a contemporary understanding of aesthetics as communication on a cultural and social level. In that context, the design research process can be thought of as a form of manifestation (for presented methodology) of the designer's and the architect's aesthetic intention, providing possible variable forms of its expression (Mako, 2009). One such methodology significantly complements the aesthetic segments of the solution and the process of the creation of the presented project review and team of authors that participated in the design of this Aquatecture experiment.

\section{Recent research on similar concepts and ideas: Models from practice}

The jury of the competition consisted of eminent experts and artists such as Edoardo Tresoldi and Anish Kapoor, whose work in practice are very complementary to the presented research methodology (Tresoldi. 2019; Kapoor.2019). In addition to these experts, works of Olafur Eliasson (Eliasson. 
2019) and Christo (Christo and Jeanne Claude. 2016), as well as structures and concepts like the Blur Building at the Swiss Expo 2002 (Dsrny. 2002), were also found to provide substantial inspiration, and they greatly influenced the presented project. Any further analysis of the works of the aforementioned authors (artists) would lead to a deepening of the presented problem and topic/ theme, as well as a possible improvement of methodology, which could deepen the way of understanding water in contemporary architecture. Such case studies would go far beyond the scope of this paper, and therefore it is expected to cover them further in some future research, in the form of a design or research process of a peculiar type of architecture - Aquatecture.

\section{CONCLUSION: COMMON SPACE OF THE VAPOURABLE SUBLIME}

In addition to the above mentioned, the architectural project review and (experimental) design research process according to the experiments from past doctoral research on relations between water and architecture, this paper deliberates those commonly known notions, while adding the common ruin as a contemporary, and very possible innovative method of revitalization of built heritage. Since the paper is funded under the "Study of Climate Change and its Impact on environment: impacts, adaptation and mitigation", the effects of humidity on the spatial structure of buildings should also be mentioned. Humidity can definitively lead to a degradation of space and structures, but in this project, well-ventilated spaces are planned, mostly under the open sky, where under the influence of insolation, the harmful effects of humidity would be avoided and prevented. While on the other hand, water vapour as a sublime character of contemporary design, especially for revitalizing the built heritage, is proposed as a unique solution in the given environment and site. Therefore, the methodology and the aquatectural project and study presented in this paper open us to possible future fields of action in the protection of the architectural heritage, merging the common space of the Vapourable Sublime of art and culture.

\section{ACKNOWLEDGEMENTS}

This paper was realized as a part of the project "Studying climate change and its influence on the environment: impacts, adaptation and mitigation" (43007) funded by the Ministry of Education, Science and Technological Development of the Republic of Serbia.

\section{REFERENCES}

_ ArchDaily. 2018. "Common ruins." ArchDaily 2008-2020 ISSN 0719-8884. Last modified October 29, 2018. Accessed March 13, 2020. https://www.archdaily.com/904760/common-ruins

_ Christo and Jeanne Claude. 2016. "The Floating Piers." Lake Iseo, Italy. Accessed March 13, 2020. https://christojeanneclaude.net/projects/the-floating-piers

_ Dsrny. 2002. "Blur Building project." Swiss Expo 2002, Yverdon les Bains, Switzerland. Accessed March 13, 2020. https://dsrny.com/project/blur-building

_ Dundović, Boris. 2019. "Vapourable Sublime", introductory text. In Vapourable Sublime, architectural project and study, authored by Boris Dundović, Lidija Lukić, Petar Tošić, Luka Stijović, Stefan Lakić and Miloš Stojković, 1. Belgrade: unpublished study.

_ Eliasson, Olafur. 2019. Accessed March 13, 2020. https://olafureliasson.net/archive/artwork

- Kapoor, Anish.2019. Accessed March 13, 2020. http://anishkapoor.com/\#works

- Mako,Vladimir. 2009. Estetika - Arhitektura, knjiga 1: sedam tematskih rasprava. Belgrade: Arhitektonski Fakultet Univerziteta u Beogradu \& Orion Art. 
_ Moore, Charles Wilard. 1994. Water and architecture. New York: Harry N. Abrams.

- Pallasmaa, Juhani. 2017. "Opipljivost i vreme - beleške o krhkoj arhitekturi." In Prostor vremena: izabrani eseji, edited by Ajla Selenić and Vladan Đokić. 51-63. Belgrade: Univerzitet u Beogradu, Arhitektonski fakultet.

_ Popović, Mihailo and Vladimir Milenković. 2015. "Evolution Digitalized: Architecture of Sublime Dream." In Keeping Up with Technologies to improve places, edited by Eva Vaništa Lazarević, Milena Vukmirović, Aleksandra Krstić-Furundžić and Aleksandra Đukić, 146-154. Newcastle upon Tyne: Cambridge Scholars Publishing.

- Stojković, Miloš. 2019. "WATER IN ARCHITECTURE: Imaginary Aquatecture space - Houses of Water." In Possible Worlds of Contemporary Aaesthetics: Aaesthetics Between History, Geography and Media: Proceedings / 21 International Congress of Aaesthetics ICA 2019, Belgrade, 2019, edited by Nataša Janković, Boško Drobnjak and Marko Nikolić, 1924-1935. Belgrade: University of Belgrade, Faculty of Architecture.

- Stojković, Miloš. 2018. "Water: inspiration in architectural space design -『methodological experiments", mentor Branko Pavić, elective course Architecture and Visual Language. Belgrade: University of Belgrade, Faculty of Architecture, unpublished study.

- Tresoldi, Edoardo. 2019.Accessed March 13,2020. https://www.edoardotresoldi.com/works/

- Wylson, Anthony. 1986. Aquatecture: architecture and water. London: The Architectural Press.

- YAC. 2018. "Common ruins Competition." YAC Itd - Vat No 02509200412 - R.E.A. Bo. 523578. Last modified March 27. 2019. Accessed March 08, 2020. (Competition Brief CR_ENG. PDF) https://www. youngarchitectscompetitions.com/competition/common-ruins\#competition; https://www.youngarchitectscompetitions.com/competition/common-ruins\#brief 